Cardiology 1997;88:I-VI

\title{
Contents, Vol. 88, 1997
}

International Journal of Cardiovascular Medicine, Surgery and Pathology

Founded 1937 as 'Cardiologia' by Bruno Kisch and Wilhelm Löffler, continued by R. Hegglin (1962-1969), I. Mahaim (1962-1965), P. Moret (1966-1969),

P.M. Galletti (1966-1979) and Jan J. Kellermann (1980-1990)

Editor-in-Chief

Joseph S. Alpert, Tucson, Ariz.

Associate Editors

G. Ewy, Tucson, Ariz. S. Goldman, Tucson, Ariz.

Editorial Assistant

J.S. Frank, Tucson, Ariz.

Editorial Board

Section 'General Cardiology'

H.J.C. Swan, Beverly Hills, Calif. (SH)

E.A. Amsterdam, Sacramento, Calif.

P.F. Cohn, Stony Brook, N.Y.

M.H. Crawford, Albuquerque, N. Mex.

J.E. Dalen, Tucson, Ariz.

P.C. Deedwania, Fresno, Calif.

R.L. Frye, Rochester, Minn.

V. Fuster, New York, N.Y.

B.J. Gersh, Washington, D.C.

T.H. Haghfelt, Odense

H. Just, Freiburg

E. Kaplinsky, Tel Hashomer

C.V. Leier, Columbus, Ohio

B.S. Lewis, Haifa

R.P. Lewis, Columbus, Ohio

B. McCallister, Jr., Ann Arbor, Mich.

I.S. Ockene, Worcester, Mass.

R.A. O'Rourke, San Antonio, Tex.

J.A. Paraskos, Worcester, Mass.

N. Rehnquist, Stockholm

L.E. Ryden, Stockholm

R.C. Schlant, Atlanta, Ga.

J.M. Sullivan, Memphis, Tenn.

K. Thygesen, Aarhus

N.K. Wenger, Atlanta, Ga.

J.T. Willerson, Houston, Tex.

R.G. Williams, Los Angeles, Calif. 
Section 'General Cardiology,

Basic Research'

H. Taegtmeyer, Houston, Tex. (SH)

S. Haunsø, Copenhagen

T.W. Smith, Boston, Mass.

Section 'Arrhythmias, Electrophysiology, and Electrocardiography' R.J. Myerburg, Miami, Fla. (SH) S.K.S. Huang, Worcester, Mass. E.N. Prystowsky, Indianapolis, Ind. J.N. Ruskin, Boston, Mass. D.M. Steinhaus, Kansas City, Mo. D.P. Zipes, Indianapolis, Ind.

Section 'CardiovascularSurgery' L.H. Cohn, Boston, Mass. J.J. Collins, Jr., Boston, Mass. T.J. Vander Salm, Worcester, Mass.

Section 'Catheterization and Interventional Cardiology' L.D. Hillis, Dallas, Tex. (SH) P.C.

Block, Portland, Oreg. B. Carabello, Charleston, S.C. S. Goldberg, Philadelphia, Pa. E.J. Topol, Cleveland, Ohio

Section 'Clinical Pharmacology' W.J. Remme, Rotterdam (SH) J.S. Karliner, San Francisco, Calif. A. Schneeweiss, Bad Schwalbach B.N. Singh, Los Angeles, Calif.

Section 'Coronary Care'

GS. Francis, Minneapolis, Minn. (SH)

K. Chatterjee, San Francisco, Calif.

R.C. Pasternak, Boston, Mass.

R. Roberts, Houston, Tex.

Section 'Diagnostic Cardiology' GA. Beller, Charlottesville, Va. (SH) J.S. Borer, New York, N.Y. A.N. De Maria, San Diego, Calif. R.E. Kerber, Iowa City, Iowa J. Maddahi, Los Angeles, Calif. J.V. Nixon, Richmond, Va. M.D. Osbakken, Philadelphia, Pa. G.M. Pohost, Birmingham, Ala. N. Reichek, Pittsburgh, Pa. J.L. Ritchie, Seattle, Wash. B.L. Zaret, New Haven, Conn. Section ‘Epidemiology and Prevention' R. Goldberg, Worcester, Mass. (SH) M. Kornitzer, Bruxelles

Section 'Pathology'

W.C. Roberts, Dallas, Tex. (SH)

H. Cuénoud, Worcester, Mass.

(SH): Section Head

KAKGER

Contents Vol. 88,1997

CARDIOLOGY

No. 1

Case Report

General Cardiology

1 Local Changes in the Plasma Endothelin Level in the Coronary Artery Immediately after Percutaneous Transluminal Coronary Angioplasty

Vojácek, J.; Lisý, O.; Simek, S.; Kraoníiek, P.; Roháí, J.; Jáchymová, M.; Jin-dra, A., Jr.

(Prague)

6 Effects of Enalapril on the Exercise Capacity and

Neurohumoral Factors during Exercise in Patients with Chronic Heart Failure

Ogino, K.; Kato, M.; Noguchi, N.; Kitamura, H.; Osaki, S.; Omodani, H,; Matsumoto, T.;

Kinugawa, T.; Miyakoda, H.; Kotake, H.; Mashiba, H. (Yonago)

48 Acute Cardiac Tamponade Secondary to Congenital Factor V Deficiency 
Schultz, S.C.; Breall, J.; Hannan, R. (Washington, D.C.)

Letter to the Editor

50 Echocardiography in Fraternal Twin Bodybuilders with One Abusing Anabolic Steroids

Dickerman, R.D.; McConathy, W.J.; Schaller, F.; Zachariah, N.Y. (Fort Worth, Tex.)

Myocardial Blood Flow Symposium

Annual Meeting of the Society of Nuclear Medicine,

Minneapolis, Minn., June 11, 1995

Cardiovascular Surgery

14 Diminished Myocardial Function Precedes Tissue Acidosis during Coronary Hypoperfusion

Shortt, K.G.; Stahl, R.F.; Soller, B.R.; Parikh, B. (Worcester, Mass.)

Cardiac Catheterization

19 Measuring Cardiac Output in Critically III Patients:

Disagreement between Thermodilution-, Calculated-, Expired Gas-, and Oxygen Consumption-

Based Methods

Sherman, M.S.; Kosinski, R.; Paz, H.L.; Campbell, D. (Philadelphia, Pa.)

Clinical Pharmacology

26 Zidovudine Therapy and Left Ventricular Function and Mass in Human Immunodeficiency

Virus-Infected Patients

Silva Cardoso, J.; Moura, B.; Mota-Míranda, A.; Rocha Gonçalves, F.; Lecour, H. (Porto)

Coronary Care

29 Determinants of Lifestyle Changes after a First Myocardial Infarction

Billing, E. (Danderyd); Bar-On, D. (Beer-Sheva); Rehnqvist, N. (Danderyd)

Noninvasive and Diagnostic Cardiology

36 Patterns of Diastolic Abnormalities during Isometric Stress in Patients with Systemic

Hypertension

Manolas, J. (Athens)

52 Towards Absolute Quantitation of Myocardial Blood Flow in Patients

Bianco, J.A. (Madison, Wise); Alpert, J.S. (Tucson, Ariz.)

54 Strategies for Extraction of Quantitative Data from Volumetric Dynamic Cardiac Positron

Emission Tomography Data

Huesman, R.H.; Klein, G.J.; Reutter, B.W.; Coxson, P.G. (Berkeley, Calif.); Botvinick, E.H.

(San Francisco, Calif.); Budinger, T.F. (Berkeley, Calif.)

62 Quantitative PET Measurements of Regional Myocardial Blood Flow: Observations in

Humans with Ischemic Heart Disease

Gewirtz, H.; Skopicki, H.A.; Abraham, S.A.; Castano, H.; Dinsmore, R.E.; Alpert, N.M.;

Fischman, A.J. (Boston, Mass.)

71 Clinical Applications of Myocardial Perfusion Assessments Made with Oxygen-15 Water and

Positron Emission Tomography

Bergmann, S.R. (St. Louis, Mo.)

80 Measurement of Coronary Blood Flow and Flow Reserve Using Magnetic Resonance

Imaging

Grist, T.M.; Polzin, J.A.; Bianco, J.A. (Madison, Wise); Foo, T.K.F.; Bernstein, M.A.

(Milwaukee, Wise); Mistretta, CM. (Madison, Wise.)

90 Quantification of Myocardial Perfusion with MRI and Exogenous Contrast Agents 
Vallée, J.-P.; Sostman, H.D.; MacFall, J.R.; Coleman, R.E. (Durham, N.C) 106 Quantitative Evaluation of Myocardial Blood Flow with [13N]Ammonia

Hutchins, G.D. (Indianapolis, Ind.)

116 Physiologic and Clinical Significance of Myocardial Blood Flow Quantitation: What Is

Expected from These Measurements in the Clinical Ward and in the Physiology Laboratory?

Bianco, J.A. (Madison, Wise); Alpert, J.S. (Tucson, Ariz.)

\section{KARGEH}

E-Mail karger@karger.ch Fax+41 613061234 http://www.karger.ch

(C) 1997 S.KargerAG, Basel

The list of contents is available at: http://www.karger.ch/journals/crd/crdcont.htm

No. 2

Exercise and Rehabilitation

Review

127 A Simplified Method of Recognizing Anterior Divisional Blocks (Hemiblocks): A Hexaxial System Approach

Constant, J. (Buffalo, N.Y.)

General Cardiology

133 Electrocardiographic Measures and Heart Rate Variability in Patients with Familial

Dysautonomia

Axelrod, F.B.; Putman, D.; Berlin, D.; Rutkowski, M. (New York, N.Y.)

141 Myocardial Ischemia and Ventricular Arrhythmias in Relation to Left Ventricular Mass and Resistance Artery Structure

Sihm, I.; Søgaard, P.; Schroeder, A.P.; Aalkjær, C; Mulvany, M.; Lederballe, O.; Thygesen, K. (Aarhus)

147 Increased Pulse Wave Velocity and Shortened Pulse Wave Transmission Time in Hypertension and Aging

Hasegawa, M.; Nagao, K.; Kinoshita, Y. (Chiba); Rodbard, D. (Bethesda, Md.); Asahina, A.

(Chiba)

152 Left Ventricular Function in Insulin-Dependent and in Non-Insulin-Dependent Diabetic

Patients: Radionuclide Assessment

Astorri, E.; Fiorina, P.; Gavaruzzí, G.; Astorri, A.; Magnati, G. (Parma)

156 Subclinical Thyroid Disorders in Patients with Dilated Cardiomyopathy

Fruhwald, F.M.; Ramschak-Schwarzer, S.; Pichler, B.; Watzinger, N.; Schumacher, M.; Zweiker, R.; Klein, W.; Eber, B. (Graz)

Clinical Pharmacology

160 Efficacy and Safety of the 3-Hydroxy-3-Methylglutaryl

Coenzyme A Reductase Inhibitor Fluvastatin in Hyperlipidemic Patients Treated with Probucol

Sasaki, S.; Nakagawa, M; Nakata, T.; Endo, N.; Miyao, K.; Kitamura, K.; Fukuyama, M,; Kitani, T.; Yamada, C. (Kyoto)

Coronary Care

166 Sinus Node Dysfunction in Acute Inferior Myocardial

Infarction. Role of Sinus Node Artery and Clinical Course in Patients with One-Vessel Coronary Artery Disease 
Kyriakidis, M.; Trikas, A.; Triposkiadis, F,; Kofinas, G.; Tsakíris, M.; Antonopoulos, A.;

Gialafos, J.; Toutouzas, P. (Athens)

170 Prompt Improvement of Left Ventricular Function and

Preservation of Topography with Combined Reperfusion and Intravenous Nitroglycerin in Acute Myocardial Infarction

Jugdutt, B.I.; Schwarz-Michorowski, B.L.; Tymchak, W.J.; Burton, J.R. (Edmonton)

Noninvasive and Diagnostic Cardiology

180 Comparison of Adenosine, Dobutamine, and Exercise

Radionuclide Ventriculography in the Detection of Coronary Artery Disease

Nagaoka, H,; Isobe, N.; Kubota, S. (Gunma); Iizuka, T. (Tano); Imai, S.; Suzuki, T.; Nagai, R.

(Gunma)

189 Assessment of Apical Hypertrophic Cardiomyopathy Using

TransoesophagealEchocardiography

Crowley, J.J.; Dardas, P.S.; Shapiro, L.M. (Cambridge)

197 Localizing Individual Coronary Artery Obstructions with the Dobutamine Stress

Echocardiography

Ho, Y.-L.; Wu, C.-C; Chao, C.-L.; Lin, L.-C; Tseng, W.-K; Chen, W.-J.; Huang, P.-J.; Lee, Y.-T. (Taipei)

203 Doppler Transmitral Flow Pattern Is an Independent Prognostic Factor in Acute Myocardial Infarction

García-Rubira, J.C.; García-Martínez, J.T.; Hidalgo, R.; Gómez-Barrado, J.J.; Rodriguez

Revuelta, M.; Rodriguez Baños, J.; Cruz, J.M. (Sevilla)

207 Determinants of Improvement in Exercise Capacity in Patients Undergoing Cardiac

Rehabilitation

Shiran, A.; Kornfeld, S.; Zur, S.; Laor, A.; Karelitz, Y.; Militianu, A.; Merdler, A.; Lewis, B.S.

(Haifa)

Case Reports

214 Role of Transesophageal Echocardiography in the

Management of Metastatic Tumors Invading the Left Atrium

Lee, T.-M.; Chen, M.-F.; Liau, C.-S.; Lee, Y.-T. (Taipei) 218 Anabolic Steroid Use as the

Possible Precipitant of Dilated Cardiomyopathy

Ferrera, P.C.; Putnam, D.L.; Verdile, V.P. (Albany, N.Y.)

Letter to the Editor

221 Variation of $\mathrm{T}$ Wave Characteristics during the Day

Koch, H.J. (Ulm)

No. 3

Review

223 Acute Coronary Syndromes

Yun, D.D.; Alpert, J.S. (Tucson, Ariz.)

General Cardiology

238 Responses of Plasma Catecholamines, Renin-Angiotensin-Aldosterone System, and Atrial Natriuretic Peptide to Exercise in Patients with Essential Hypertension

Kinugawa, T.; Endo, A.; Kato, M.; Kato, T.; Ahmmed, G.U.; Omodani, H.; Osaki, S.; Ogino, K; Hisatome, I.; Miyakoda, H.; Fujimoto, Y.; Yoshida, A.; Shigemasa, C. (Yonago)

246 Prediction of Left Ventricular Dysfunction in Coronary Artery Disease from Clinical and Exercise Test Findings 
Sjöland, H.; Herlitz, J.; Lamm, C; Hartford, M.; Caidahl, K. (Göteborg)

254 Effects of Electroconvulsive Therapy on Cardiac Function in Patients without Heart Disease Fuenmayor, A.J.; El Fakih, Y.; Moreno, J.; Fuenmayor, A.M. (Mérida)

General Cardiology, Basic Research

258 Carnitine Palmitoyltransferase in Patients with Cardiac

Ischemia due to Atherosclerotic Coronary Artery Disease and in Patients with Idiopathic Dilated Cardiomyopathy

Maurer, I. (Bonn); Zierz, S. (Halle-Wittenberg)

Arrhythmias, Electrophysiology and Electrocardiography

264 Stroke in Paced Patients with Sick Sinus Syndrome:

Relevance of Atrial Mechanical Function, Pacing Mode and Clinical Characteristics

Mattioli, A.V.; Tarabini Castellani, E.; Fusco, A.; Paolillo, C; Mattioli, G. (Modena)

Catheterization and Interventional Cardiology

271 Effect of the Balloon-Anulus Ratio on the Intermediate and Follow-Up Results of

Pulmonary Balloon Valvuloplasty

Narang, R.; Das, G.; Dev, V.; Goswami, K; Saxena, A.; Shrivastava, S. (New Delhi)

Clinical Pharmacology

277 Discontinuation of Antihypertensive Therapy: Prevalence of Relapses and Predictors of Successful Withdrawal in a Hypertensive Community

Schmieder, R.E. (Erlangen-Nürnberg); Rockstroh, J.K. (Bonn); Gatzka, CD. (Erlangen-

Nürnberg); Rüddel, H.; Schächinger, H. (Bonn)

Contents

Cardiology Vol. 88, 1997

III

Coronary Care

Catheterization and Interventional Therapy

285 Potential Proischemic Effect of Early Enalapril in Hypotension-Prone Patients with Acute Myocardial Infarction

Søgaard, P; Thygesen, K.; CONSENSUS II Holter Substudy Group (Aarhus)

Case Reports

292 Dynamic Left Ventricular Outflow Tract Obstruction in Critically III Patients: Role of

Transesophageal Echocardiography in Therapeutic Decision Making

Madu, E.C.; Brown, R.; Geraci, S.A. (Memphis, Tenn.) 296 Giant Cell Myocarditis due to

Coxsackie B2 Virus Infection

Meyer, T.; Grumbach, I.M.; Kreuzer, H.; Morguet, A.J. (Göttingen)

300 Transseptal Mitral Balloon Valvotomy in Patients with Atrial Septal Äneurysms

Rittoo, D.; Sutherland, G.R.; Shaw, T.R.D. (Edinburgh)

Letters to the Editor

305 Gangliosides in Chagas' Heart Disease: A Potential Treatment for a Disease without

Treatment

Bestetti, R.B. (Ribeirão Preto)

308 Nomenclature Problems in Cardiology

Cheng, T.O. (Washington, D.C.)

307 Announcements 
No. 4

General Cardiology

309 Association of a Deletion Polymorphism of the Angiotensin-Converting Enzyme Gene with Left-Ventricular Hypertrophy in Japanese Women with Essential Hypertension; Multicenter Study of 1,919 Subjects

Kimura, M.; Yokota, M.; Fujimura, T.; Kato, S.; Hirayama, H. (Nagoya); Tsunekawa, A. (Okazaki); Maeda, M. (Chita); Inagaki, H. (Toyota); Ogawa, S. (Kagamihara); Nakashima, N. (Nagoya); Yamada, Y. (Obu)

315 Long-Term Changes in Left Ventricular Mass, Chamber Size and Function after Valve Replacement in Patients with Severe Aortic Stenosis and Depressed Ejection Fraction Pelà, G; La Canna, G; Metra, M.; Ceconi, C; Berra Centurini, P.; Alfieri, 0.; Visioli, O. (Brescia) Arrhythmias, Electrophysiology and Electrocardiography

323 DDD(R) Pacing with Automatic Mode Switch in Patients with Paroxysmal Atrial Fibrillation following AV Nodal Ablation

Schuchert, A. (Hamburg); van Langen, H.; Michels, K. (Maastricht); Meinertz, T. (Hamburg) 328 QRS Polarity on 12-Lead Surface ECG

A Criterion for the Differentiation of Right and Left Posteroseptal Accessory Atrioventricular Pathways

Diker, E.; Özdemir, M.; Tezcan, U.K.; Aydo7/8du, S.; Korkmaz, §.; §a§maz, A.; Sözütek, Y.; Kütük, E.; Göksel, S. (Ankara)

Cardiovascular Surgery

333 Serial Prognostic Capabilities of Electrocardiographic Indices of Infarcted and Hibernating Myocardium in Predicting Short- and Long-Term Outcome following Coronary Artery Bypass Surgery

Holmvang, L.; Lyck, F. (Copenhagen/Durham, N.C.); Clemmensen, P. (Copenhagen); Behar, V. (Durham, N.C.); Maynard, C. (Seattle, Wash.); Grande, P. (Copenhagen); Wagner, G.S.

(Durham, N.C.)

340 Left Ventricular Endoaneurysmorrhaphy: Effect on Left Ventricular Size, Shape and Function

Çíçek, S.; Demirkiliç, U.; Tatar, H.; Bingöl, H.; Öztürk, Ö.Y. (Ankara)

346 Laser versus Radiofrequency Catheter Ablation of Ventricular Myocardium in Dogs: A

Comparative Test

Weber, H.P.; Heinze, A.; Enders, S. (Munich); Ruprecht, L.; Unsold, E. (Oberschleissheim)

Clinical Pharmacology

353 Effect of Gallopamil on Myocardial Microperfusion in Patients with Stable Effort Angina: A Randomized, Cross-Over, Double-Blind, Placebo-Controlled Trial

Acanfora, D. (Campoli del Monte Taburno); Vitale, D.F.; Rengo, C; Iannuzzi, G.L. (Naples); Furgi, G.; Picone, C; Rossi, M.; Trojano, L. (Campoli del Monte Taburno); Rengo, F. (Campoli del Monte Taburno/Naples)

Coronary Care

361 Pathophysiology of Precordial ST-Segment Depression in Inferior Wall Acute Myocardial Infarction: An Echocardiographic Appraisal

Hasdai, D.; Jabara, R.; Sclarovsky, S.; Imbar, S.; Sagie, A. (Petah-Tikva)

367 Causal Attribution by Patients, Their Spouses and the Physicians in Relation to Patient Outcome after a First Myocardial Infarction. Subjective and Objective Outcome

Billing, E. (Danderyd); Bar-On, D. (Negev); Rehnqvist, N. (Danderyd) 
Noninvasive and Diagnostic Cardiology

373 Estimation of Pulmonary Capillary Wedge Pressure from M-Mode Mitral Echograms

Akita, S.; Ohte, N.; Narita, H.; Hashimoto, T,; Kobayashi, K.; Fujinami, T. (Nagoya)

379 Dobutamine Stress Echocardiography Compared with Exercise Thallium-201 Single-Photon

Emission Computed Tomography in Detecting Coronary Artery Disease - Effect of Exercise

Level on Accuracy

Ho, Y.-L.; Wu, C.-C; Huang, P.-J.; Tseng, W.-K.; Lin, L.-C; Chieng, P.-U.; Chen, M.-F.; Lee, Y.-T. (Taipei)

386 Assessment of the Functional Significance of Coronary Artery Stenosis by DobutamineAtropine Stress Echocardiography

Ho, Y.-L.; Wu, C.-C; Lin, L.-C; Liu, Y.-B.; Chen, W.-J.; Chen, M.-F.; Liau, C.-S.; Lee, Y.-T. (Taipei)

393 Clinical Feasibility of Echocardiographic Automated Border Detection in Monitoring Left

Ventricular Response to Acute Changes of Preload in Normal Subjects

Grandi, A.M.; Bignotti, M.; Bertolini, A.; Gaudio, G; Zanzi, P.; Guasti, L.; Nardo, B.; Venco, A.

(Varese)

392 Announcement

No. 5

General Cardiology

397 Clinical and Echocardiographic Findings in HIV Patients with Pericardial Effusion

Moreno, R.; Villacastín, J.P.; Bueno, H.; Lopez de Sá, E.; López-Sendón, J.L.; Bobadilla, J.F.;

García-Fernández, M.A.; Delcán, J.L. (Madrid)

401 Brain Natriuretic Peptide Is a Sensitive Indicator of Impaired Left-Ventricular Function in Elderly Patients with Cardiovascular Disease

Yamada, Y.; Goto, J. (Aichi); Yokota, M. (Nagoya) 408 A New Cardiology Patient Simulator

Takashina, T. (Osaka); Shimizu, M. (Tokyo); Katayama, H. (Kyoto)

414 Endothelium-Dependent Dilation of the Coronary Arteries in Syndrome X: Effects of the

Cold Pressor Test

Sanderson, J.E.; Woo, K.S.; Chung, H.K.; Chan, W.M.; Tse, K.K. (Hong Kong); White, H.D.

(Auckland)

IV

Cardiology Vol. 88, 1997

Contents

General Cardiology, Basic Research

418 Beta-Blockade Prevents Ventricular Failure Following Aortic Regurgitation in Rabbits

Suzuki, M; Yoshikawa, T.; Wainai, Y.; Nagami, K.; Handa, S. (Tokyo)

Cardiovascular Surgery

425 Endothelium-Dependent and Endothelium-Independent Flow Regulation in Coronary

Vascular Regions Supplied by Arterial and Venous Bypass Grafts

Hartmann, A. (Leipzig); Lahoda, T.; Burger, W. (Frankfurt); Beyersdorf, F. (Freiburg); Schräder,

R.; Satter, P. (Frankfurt)

Catheterization and Interventional Cardiology

433 Use and Limitations of Immediate Postprocedural Intracoronary Doppler Blood Flow

Measurements for Predicting Late Result after Coronary Balloon Angioplasty

Results of a Pilot Study 
Lewis, B.S.; Kattan, D.; Laughrun, D. (Los Angeles, Calif./Haifa)

Coronary Care

441 Prognostic Significance of Infarction Location in Patients with Recurrent Myocardial

Infarction

Kornowski, R. (Tel Aviv); Goldbourt, U.; Reicher-Reiss, H.; Reisin. L.; Haim, M.; Moshkovitz, Y.; Caspi, A.; Behar, S. (Tel Hashomer); SPRINT Study Group

Noninvasive and Diagnostic Cardiology

446 QRS Prolongation Measured by a New Computerized Method: A Sensitive Marker for

Detecting Exercise-Induced Ischemia

Cantor, A.; Goldfarb, B.; Aszodi, A.; Battler, A. (Beer-Sheva)

453 Exercise Testing in Patients with Chest Pain and Normal Coronary Arteries: Improving Test Specificity by Use of a Simple Logistic Model

Shiran, A.; Halon, D.A.; Laor, A.; Merdler, A.; Karban, E.; Lewis, B.S. (Haifa)

Epidemiology and Prevention

460 Can ECG Changes Predict the Long-Term Outcome in Patients Admitted to Hospital for Suspected Acute Myocardial Infarction?

Lim, L.L.-Y.; Kinlay, S.; Fisher, J.D.; Dobson, A.J.; Heller, R.F. (Newcastle)

Exercise and Cardiac Rehabilitation

468 Exercise Training in Mild Hypertension: Effects on Blood

Pressure, Left Ventricular Mass and Coagulation Factor VII and Fibrinogen

Zanettini, R.; Bettega, D.; Agostoni, O.; Ballestra, B.; del Rosso, G.; Di Michele, R.; Mannucci, P.M. (Milan)

Case Reports

474 Paroxysmal Atrial Tachycardia with Second-Degree Atrioventricular Block

Chen, M.-C; Guo, G.B.-F.; Chang, K.-C. (Kaohsiung)

478 Electromechanical Dissociation following Verapamil and Propranolol Ingestion: A

Physiologic Profile

Waxman, A.B.; White, K.P.; Trawick, D.R. (New Haven, Conn.)

482 Rescue PTCA for a Totally Occluded Left Main Coronary Artery in Acute Myocardial

Infarction with Cardiogenic Shock: Technical Success and Long-Term Survival

La Vecchia, L.; Castellani, A.; Bedogni, F.; Vincenzi, M. (Vicenza/Verona)

Letter to the Editor

486 A Man in the Thunderstorm: Coronary Injuries and Electric Shock

Víanello, F. (Padua)

485 Announcement

No. 6

General Cardiology

487 Elevated Serum Cardiac Markers in Asymptomatic Marathon Runners after Competition: Is the Myocardium Stunned?

Siegel, A.J.; Sholar, M.; Yang, J.; Dhanak, E.; Lewandrowski, K.B. (Boston, Mass.) 492 Shortand Long-Term Prognosis after Coronary Artery Bypass Grafting in Relation to Smoking Habits Herlitz, J.; Haglid, M.; Albertsson, P.; Westberg, S.; Karlson, B.W.; Hartford, M.; Lurje, L.;

Caidahl, K. (Göteborg)

498 Doppler Echocardiographic Assessment of Left Ventricular Diastolic Function in Myotonic Dystrophy 
Fragola, P.V.; Caló, L; Luzi, M.; Mammarella, A.; Antonini, G. (Rome) 503 Hyperinsulinemia in Patients with Spastic Angina Pectoris

Miyawaki, R.; Urabe, Y.; Furuki, T.; Miyoshi, K.; Wakiyama, T.; Moroe, K.; Hiroki, T.

(Fukuoka)

509 Daily Distribution of Episodes of Acute Cardiogenic Pulmonary Edema

Pasqualetti, P.; Casale, R. (L'Aquila) 513 Cardiac Involvement in Behçet's Disease

Morelli, S.; Perrone, C; Ferrante, L.; Sgreccia, A.; Priori, R.; Voci, P.; Accorinti, M.; Pivetti-

Pezzi, P.; Valesini, G. (Roma)

General Cardiology, Basic Science

518 Protein Turnover in Compensated Chronic Aortic Regurgitation

King, R.K.; Magid, N.M.; Opio, G.; Borer, J.S. (New York, N.Y.)

Cardiovascular Surgery

526 Effects of Antegrade versus Combined Antegrade/Retrograde Cardioplegia on Postoperative Septal Wall Motion in Patients Undergoing Open Heart Surgery

Chouraqui, P.; Rabinowítz, B.; Livschitz, S.; Horoszowsky, D.; Kaplinsky, E. (Tel Hashomer);

Smolinsky, A. (Tel Aviv)

Cardiac Catheterization and Interventional Cardiology

530 Dislodgement of a Wiktor Stent during Intracoronary Ultrasound Examination

Sturm, M,; Hausmann, D.; Mügge, A.; Blessing, E.; Amende, I. (Hannover)

533 Early Detection of Myocardial Ischemia after Successful Percutaneous Coronary

Angioplasty

Jain, A. (San Antonio, Tex.)

Coronary Care

540 Clinical Significance of the Urinary Oxygen Tension in Patients with Ischemic Heart

Disease

Kitashiro, S.; Sugiura, T.; Takayama, Y.; Tamura, T.; Izuoka, T.; Inada, M.; Iwasaka, T. (Osaka)

544 Pericardial Effusion after Streptokinase for Acute Myocardial Infarction: An

Echocardiographic 1-Year Follow-Up Study

Otasevic, P.; Ne§kovic, A.N.; Bojic, M.; Popovic, A.D. (Belgrade) 548 Early Administration of

Ramipril in Acute Myocardial

Infarction: Neurohormonal and Hemodynamic Effects and Tolerability

van der Ent, M.; Remme, W J.; Bartels, G.L.; Kruijssen, D.A.C.M.; Krauss, X.H.; van

Hoogenhuyze, D.C.A. (Rotterdam)

Noninvasive and Diagnostic Cardiology

556 Simultaneous Dobutamine Stress Echocardiography and

Thallium-201 Perfusion Imaging for the Detection of Coronary Artery Disease

Huang, P.-J.; Ho, Y.-L.; Wu, C.-C; Chao, C.-L.; Chen, M.-F.; Chieng, P.-U.; Lee, Y.-T. (Taipei)

563 Influence of Left Ventricular Diastole on Left Atrial Appendage Blood Flow in Patients with Nonrheumatic Atrial Fibrillation

Lin, J.-M. (Taichung); Hsu, K.-L.; Hwang, J.-J.; Tseng, Y.-Z. (Taipei)

Contents

Cardiology Vol. 88, 1997

$\mathrm{V}$

569 Risk Stratification prior to Vascular Surgery: Does the Location of a Dipyridamole Thallium Scintigram Defect Provide Prognostic Information? 
Nguyen, T.T.; Amsterdam, E.A.; Schaefer, S. (Davis, Calif.)

576 On-Line Computerized Vectorcardiography: Influence of Body Position, Heart Rate, Radiographic Contrast Fluid and Mrocardial Ischemia

Jensen, S.M.; Häggmark, S.; Johansson, G.; Näslund, U. (Umeå)

585 PVF Velocity Pattern in Patients with Heart Failure: Transesophageal Echocardiographic

Assessment

Vitarelli, A.; Ferro Luzzi, M.; Penco, M.; Ciciarello, F.; Fedele, F.; Dagianti, A. (Rome)

Exercise and Cardiac Rehabilitation

595 Effect of Controlled Exercise Training in Coronary Artery Disease Patients with and without

Left Ventricular Dysfunction Assessed by Cardiopulmonary Indices

Klainman, E. (Givatayim/Petah Tiqva/Tel Aviv); Fink, G.; Zafrir, N.; Pinchas, A.; Spitzer, S.

(Petah Tiqva/Tel Aviv)

Case Reports

Suppl. 1

Proceedings of the Nisoldipine CC Investigators' Meeting

Wiesbaden, Germany, May 10-11,1996

Session I

The Role of Calcium Channel Blockers in the Management of Ischaemic Heart Disease

Guest Editor: G. Heusch, Essen

Session II

The Role of Calcium Channel Blockers in the Management of Hypertension

Guest Editor: J.L. Palma-Gámiz, Madrid

Suppl. 2

601 Spongy Myocardium

Reynen, K.; Bachmann, K.; Singer, H. (Erlangen)

603 Anomalous Origin of All Coronary Arteries from the Pulmonary Trunk

Heusch, A. (Düsseldorf); Quagebeur, J. (New York, N.Y.); Paulus, A.; Krogmann, O.N.;

Bourgeois, M. (Düsseldorf)

609 Viable but Denervated Right Ventricular Myocardium: A Case of Eisenmenger Reaction

Hirose, Y.; Ishida, Y.; Hayashida, K.; Satoh, T.; Shimotsu, Y.; Nishimura, T. (Osaka)

613 Primary Cardiac Lymphoma with Infiltration of the Atrioventricular Node: Remission with

Reversal of the Atrioventricular Block Induced by Chemotherapy

Nakayama, Y.; Uchimoto, S.; Tsumura, K.; Morii, H. (Osaka)

Recent Changes in the Treatment of Congestive Heart Failure

Guest Editor: Pieter Adriaan van Zwieten, Amsterdam

Suppl. 3

Slow Release Nifedipine: End-Organ Protection and Prevention of Cardiovascular Disease

Guest Editor: Shimon Braun, Tel Aviv

617 Author Index Vol. 88619 Subject Index Vol. 88

KAHGEK

S. Karger

Medical and Scientific Publishers Basel $\cdot$ Freiburg $\cdot$ Paris $\cdot$ London New York $\cdot$ New Delhi

Bangkok Singapore $\cdot$ Tokyo $\cdot$ Sydney

Drug Dosage 
The authors and the publisher have exerted every effort to ensure that drug selection and dosage set forth in this text are in accord with current recommendations and practice at the time of publication. However, in view of ongoing research, changes in government regulations, and the constant flow of information relating to drug therapy and drug reactions, the reader is urged to check the package insert for each drug for any change in indications and dosage and for added warnings and precautions. This is particularly important when the recommended agent is a new and/or infrequently employed drug.

All rights reserved.

No part of this publication may be translated into other languages, reproduced or utilized in any form or by any means, electronic or mechanical, including photocopying, recording, microcopying, or by any information storage and retrieval system, without permission in writing from the publisher or, in the case of photocopying, direct payment of a specified fee to the Copyright Clearance Center (see 'General Information').

(C) Copyright 1997 by S. Karger AG, P.O. Box, CH-4009 Basel (Switzerland) Printed in Switzerland on acid-free paper by Reinhardt Druck, Basel

VI

Cardiology Vol. 88, 1997

Contents 